\title{
The relationship between drug therapy adherence and the results of blood pressure targets achievement in hypertensive patients with dyslipidemia complications at Government Hospital in Yogyakarta
}

\author{
Andriana Sari*, Faridah Baroroh, Fitriani Puji Astuti \\ Faculty of Pharmacy, Universitas Ahmad Dahlan \\ Jl. Prof. Dr. Soepomo, Janturan, Yogyakarta, Indonesia
}

\begin{abstract}
Hypertension is a chronic disease that affects most people. Almost every people have certain specific factors that can cause this disease to increase. One of which is inadequate physical activity so that cholesterol levels remain and tend to get higher, which is a risk factor for heart and blood vessel disorders. Patients with this disease and having dyslipidemia complications must treat with appropriate therapy until reaching success. The patient's adherence determines the success of the treatment. Therefore the purpose of this research is to assess the relationship. Its objects were hypertensive patients at the Government Hospital in Yogyakarta. The specialty of the hypertensive patient is having dyslipidemia complications. The study uses non-experimental with a cross-sectional study. The sample was selected based on the purposive sampling technique in December 2018-February 2019. The measurement of therapy adherence used MARS questionnaire and the achievement of therapy targets through secondary data on patient blood pressure. Chi-square test was chosen to determine the relationship between 2 variables, which are therapy adherence and achieving blood pressure targets. The sample in this study were 47 respondents, of which $53.2 \%$ of the patients were $<60$ years old, in which $51.1 \%$ of them were female. The results showed that patients who were adherent to therapy were $25.5 \%$, and those who were not were $74.5 \%$. The results of achieving the blood pressure target are known to be $68.1 \%$. The data analysis results showed that the one-way hypothesis in Fisher's test obtaining $\mathrm{p}$-value $=0.171(\mathrm{p}>0.05)$ was no relationship between adherence and target achievement. Therefore the results of this study concluded that there is no relationship between drug therapy adherence and blood pressure targets achievement.
\end{abstract}

Keywords: hypertensive, dyslipidemia, adherence, blood pressure target achievement, MARS

\footnotetext{
*Corresponding author:

Andriana Sari

Faculty of Pharmacy, Universitas Ahmad Dahlan

J1. Prof. Dr. Soepomo, Janturan, Yogyakarta, Indonesia

Email: andriana@pharm.uad.ac.id
} 


\section{INTRODUCTION}

Hypertension is a disease that affects many people in the world. The disease presents an increase of more than $140 \mathrm{mmHg}$ at systolic blood pressure and more than $90 \mathrm{mmHg}$ at diastolic (Weber et al., 2014). The prevalence of hypertension in Indonesia occurs at age> 18 years as much as $25.8 \%$ (Kesehatan, 2013). In Yogyakarta, most of this disease is 26.7\% (Anonim, 2015), and is the second of the ten most common conditions in Bantul district (Dinkes, 2014).

The increase of blood pressure causes the heart to work faster, and blood does not flow properly, so there is a possibility that there will be a decrease in the function of several organs in the body. The factors causing this kind of occurrence in each individual can be so varied that it is not easy to determine. Some of the most common causes are eating high salted foods, energy-dense foods, fatty foods, and a lack of fruit and vegetables. These all can increase the risk of increased blood pressure and cardiovascular disease (Ozemek et al., 2018) . World health organization (Day, 2013) estimates that high cholesterol levels (hypercholesterolemia) can lead to stroke (20\%) and heart problems (> $50 \%)$. And to prevent this occurrence, drug therapy must be successful.

The patient's adherence to taking the drug influencing the therapy's success, so that blood pressure targets achieved and prevent disease complications. Patients with hypertension who do not adhere to taking medication according to the rules of use that have been conveyed by health workers cause uncontrolled blood pressure and lead to death (Krousel-Wood et al., 2009). Therefore it is necessary to do findings in drug therapy adherence and the achievement of blood pressure targets in hypertensive patients with dyslipidemia complications at the Government Hospital in Yogyakarta.

\section{MATERIALS AND METHOD}

The non-experimental findings with a cross-sectional study were chosen. Its primary data is MARS questionnaire to determine patient adherence to drug therapy, and its secondary data from medical records is blood pressure form to assess the achievement of blood pressure targets. The study samples were hypertensive patients with dyslipidemia complications having the inclusion or exclusion criteria and was undergoing outpatient care at the Government Hospital in Yogyakarta. The inclusion criteria were male or female patients, aged $\geq 18$ years, with antihypertensive therapy for at least three months. The exclusion criteria were pregnant women with pre-eclampsia, kidney and liver disorders, incomplete medical record data, and questionnaires.

The initial findings procedure was by applying for a finding permit and obtaining ethical approval number 011805083 from the Findings Ethics Committee of Ahmad Dahlan University. The selection of respondents is based on diagnosis by doctors according to inclusion and exclusion criteria. The respondents have explained the study to be carried out and were asked for approval by filling out the consent form. They must answer MARS questionnaire to measure adherence in taking drugs after the last three months of consumption. The next step was checking the questionnaire results and collecting blood pressure data as much as $1 \mathrm{x}$ measurement after 3 months of taking the drug through medical record data. Univariate analysis was used to determine the percentage of respondent characteristics, including age, gender, education level, occupation, habits (exercise, diet, smoking, coffee and alcohol consumption), disease complications, medications received by patients, adherence, and blood pressure. Bivariate analysis using Chi-square was used to determine the relationship between 2 variables: therapy adherence and achievement of blood pressure targets (significance value $\mathrm{p}<0.05)$.

\section{RESULT AND DISCUSSION \\ Patient characteristics data}

The hypertensive patients' characteristics with dyslipidemia complications in Government Hospital in Yogyakarta are presented in Table 1 . The results showed that patients aged $<60$ years were $53.2 \%$. (Kishore et al., 2016) says that the potential for hypertension will be more significant at the 
age of over 35 years $(21.8 \%$ ) with an odds ratio of 3.60 (range ratio $2.11-6.15)$ and p-value $=0.01$. It means that people over 35 years old are more at risk of developing hypertension.

Table 1. Chi-square analysis on the relationship between patient characteristics and therapy adherence, and chi-square analysis on the relationship between characteristics and blood pressure targets achievement of hypertensive patients with dyslipidemia complications at the Government Hospital in Yogyakarta in the period December 2018-February 2109

\begin{tabular}{|c|c|c|c|c|c|}
\hline \multicolumn{4}{|c|}{ Patient characteristics } & \multicolumn{2}{|c|}{ Chi-square Analysis (p-value) } \\
\hline Category & & $\begin{array}{c}\text { Number of } \\
\text { patients } \\
(\mathrm{n}=47)\end{array}$ & $\begin{array}{c}\text { Percentage } \\
(100 \%)\end{array}$ & $\begin{array}{c}\text { Therapy } \\
\text { adherence }\end{array}$ & $\begin{array}{c}\text { Achievement } \\
\text { of Therapy } \\
\text { Target }\end{array}$ \\
\hline \multicolumn{6}{|l|}{ Age } \\
\hline \multirow{2}{*}{\multicolumn{2}{|c|}{$\begin{array}{l}<60 \text { years } \\
\geq 60 \text { years }\end{array}$}} & 25 & 53.2 & 0.057 & 0.495 \\
\hline & & 22 & 46.8 & & \\
\hline \multicolumn{6}{|l|}{ Sex } \\
\hline \multicolumn{2}{|l|}{ Man } & 23 & 48.9 & 0.285 & 0.206 \\
\hline \multicolumn{2}{|l|}{ Woman } & 24 & 51.1 & & \\
\hline \multicolumn{6}{|c|}{ Occopation } \\
\hline \multicolumn{2}{|c|}{ Unemployed } & 8 & 17.0 & 0.203 & 0.327 \\
\hline \multicolumn{2}{|c|}{ Employed } & 39 & 83.0 & & \\
\hline \multicolumn{6}{|c|}{ Education } \\
\hline \multirow{2}{*}{\multicolumn{2}{|c|}{$\begin{array}{l}\text { Did not complete basic education } \\
\text { Completed basic education }\end{array}$}} & 6 & 12.7 & 0.324 & 0.469 \\
\hline & & 41 & 87.3 & & \\
\hline \multicolumn{6}{|l|}{ Lifestyle } \\
\hline \multirow[t]{2}{*}{ Exercise } & : Yes & 32 & 68.1 & 0.099 & 0.303 \\
\hline & No & 15 & 31.9 & & \\
\hline \multirow{2}{*}{ Diet } & : Yes & 31 & 66.0 & 0.227 & 0.238 \\
\hline & No & 16 & 34.0 & & \\
\hline \multirow{2}{*}{ Habit } & : Good & 29 & 61.7 & $0.038 *$ & 0.320 \\
\hline & Bad & 18 & 38.3 & & \\
\hline \multicolumn{4}{|c|}{ Types of complications } & & \\
\hline \multirow{2}{*}{\multicolumn{2}{|c|}{$\begin{array}{l}\text { Dyslipidemia/CAD+DM } \\
\text { Dyslipidemia+other complications }\end{array}$}} & 35 & 74.5 & 0.481 & 0.281 \\
\hline & & 12 & 25.5 & & \\
\hline
\end{tabular}

Note: $\mathrm{CAD}=$ coronary artery disease, $\mathrm{DM}=$ Diabetes Mellitus

*significance $<0.05$ means that there is a significant association between patient characteristics based on lifestyle and drug therapy adherence

The research was dominated by women $(51,1 \%)$. Women usually get high blood pressure after menopause. Findings on this have been conducted on thousands of women in America. The results showed that higher cholesterol levels in middle-aged women were a potent cause of hypertension. In contrast, women with high HDL were found to have a decreased risk of hypertension slightly (Nikolov et al., 2015) . The results showed that the majority of patients were workers (83.0\%). Low physical activity in office workers or people who sit more than 5 hours a day, working with relying on automatic machines, are more at risk of suffering hypertension (Bosu, 2017). The findings data shows that most of the patients' latest education has graduated from primary education so they may better understand drug use instructions to improve therapy adherence and achieve blood pressure targets.

The results showed that the lifestyle of patients who did physical activity/sports was $68.1 \%$. Physical activity or sports are part of the risk of hypertension (Hardati and Ahmad, 2013). The results also showed that patients who did a diet were 66.0\%. A finding in Africa showed that excess fat consumed is the cause of hypertension (Ramirez et al., 2010). So the findings result is divided into two categories of habits, which are good and less. 
Good habits are defined when the patient does not consume alcohol, tea, coffee, or smoke. Bad habits are determined when the patient drinks alcohol, tea, coffee, and smokes, or just one of these. The results showed that the patients had good habits as much as $61.7 \%$. Drinking coffee can increase blood pressure briefly but then return to normal. There is no significant relationship between coffee drinking habits and increased blood pressure in adults (Bistara and Kartini, 2018).

The findings showed that most complications suffered by patients were hypertension with dyslipidemia complications (CAD) and Diabetes Mellitus (74.5\%). They were also had other diseases such as OA, IHD, asthma, cholelithiasis, CHF, BPH, HHD, hyperuricemia, LBP, GERD, and cephalgia. Based on patients' characteristics toward therapy adherence, it concluded that there was no significant relationship ( $p>0.05$ ) on each aspect unless the factors of lifestyle in the form of customs patients do not consume alcohol, tea, coffee, or smoke obtained $p$-value $=0.038$. The relationship between patient characteristics and therapeutic targets' achievement also showed no significant relation $(\mathrm{p}>0.05)$.

\section{Drug profile}

The results of the study on antihypertensive and antidyslipidemic drugs obtained by patients are presented in Table 2.

Table 2. Antihypertensive and antidyslipidemic drugs received by hypertensive patients with dyslipidemia complications at the Government Hospital in Yogyakarta for the period December 2018-February 2019

\begin{tabular}{|c|c|c|c|c|}
\hline \multirow{2}{*}{ Antihypertensive Therapy } & \multicolumn{3}{|c|}{ Antidyslipidemic Therapy } & \multirow{2}{*}{$\begin{array}{l}\text { Total } \\
(\%)\end{array}$} \\
\hline & Statin & Fibrate & $\begin{array}{l}\text { Combination } \\
\text { statin+fibrat }\end{array}$ & \\
\hline CCB (amlodipine) & $5(10.7 \%)$ & $3(6.4 \%)$ & $1(2.1 \%)$ & \multirow{11}{*}{$\begin{array}{c}47 \\
(100)\end{array}$} \\
\hline ARB (irbesartan, candesartan) & $4(8.5 \%)$ & $2(4.3 \%)$ & $2(4.3 \%)$ & \\
\hline Beta Bloker (bisoprolol) & $0(0 \%)$ & $1(2.1 \%)$ & $0(0 \%)$ & \\
\hline ARB+Beta Bloker (valsartan/candesartan+ bisoprolol) & $1(2.1 \%)$ & $4(8.5 \%)$ & $0(0 \%)$ & \\
\hline $\mathrm{ARB}+\mathrm{CCB}$ (irbesartan/candesartan/ valsartan+ amlodipine) & $8(17.0 \%)$ & $5(10.7 \%)$ & $5(10.7 \%)$ & \\
\hline ARB + Diuretic (candesartan+ furosemide) & $0(0 \%)$ & $1(2.1 \%)$ & $0(0 \%)$ & \\
\hline $\mathrm{ARB}+\mathrm{ARB}$ (valsartan+candesartan) & $0(0 \%)$ & $1(2.1 \%)$ & $0(0 \%)$ & \\
\hline $\begin{array}{c}\mathrm{ARB}+\mathrm{CCB}+\text { Beta Bloker ( valsartan+ amlodipine+ } \\
\text { bisoprolol) }\end{array}$ & $0(0 \%)$ & $1(2.1 \%)$ & $0(0 \%)$ & \\
\hline $\begin{array}{c}\text { ARB+Diuretic+Beta Bloker } \\
\text { (candesartan+furosemide+ bisoprolol) }\end{array}$ & $1(2.1 \%)$ & $0(0 \%)$ & $0(0 \%)$ & \\
\hline $\begin{array}{c}\mathrm{ARB}+\mathrm{ARB}+\mathrm{Beta} \text { Bloker (candesartan+ irbesartan+ } \\
\text { bisoprolol) }\end{array}$ & $1(2.1 \%)$ & $0(0 \%)$ & $0(0 \%)$ & \\
\hline $\mathrm{ARB}+\mathrm{CCB}+$ Diuretic (candesartan,amlodipine, furosemide) & $0(0 \%)$ & $1(2.1 \%)$ & $0(0 \%)$ & \\
\hline
\end{tabular}

Note: CCB: Calcium Channel Blocker, ARB: Angiotensin Receptor Blocker,

Data on antihypertensive drug therapy were accepted from the findings. Those are single therapy, a combination of two drugs, and an assortment of three drugs from various antihypertensive groups. This available antihypertensive therapy is used in patients with stage I hypertension, and two or three combination therapy is used in patients with stage II hypertension. (Bakris et al., 2003) Antihypertensive and antidyslipidemic drugs, which were often used by the patients, were CCB combination with ARB and statin (17\%). (Last et al., 2017) suggest that statin therapy should be prescribed for secondary prevention in patients with known ASCVD (atherosclerotic cardiovascular disease), unless contraindicated. The more significant amount of drugs used by the patient may affect adherence in taking drugs. 


\section{Therapeutic adherence}

Therapeutic adherence in the research was measured based on the results of filling out MARS questionnaire. Measurement of patient adherence to therapy was carried out once after consuming the doctor's drug for three months. To measure the consumption of antihypertensive and anti-cholesterol drugs, they were given two MARS questionnaires. Patients are said to be adherent in taking drugs if the total score from the measurement of antihypertensive and anti-cholesterol therapy is known to have each score $=25$. It is said to be non-adherent if the score of the two measures or one of them is a score $<25$. Data based on patient therapy are presented in Table 3 .

Table 3. Therapy adherence of hypertensive patients with dyslipidemia complications at Government Hospital in Yogyakarta for period December 2018-February 2019

\begin{tabular}{lccc}
\multicolumn{1}{c}{$\begin{array}{c}\text { Therapy } \\
\text { Adherence }\end{array}$} & $\begin{array}{c}\text { Numbers of Respondent } \\
(\mathbf{n = 4 7 )}\end{array}$ & $\begin{array}{c}\text { Percentage } \\
(\mathbf{1 0 0 \%})\end{array}$ & $\boldsymbol{P}$-Value \\
\hline Adherent & 12 & 25,5 & $0,000 *$ \\
Non-adherent & 35 & 74,5 & 0,5 \\
\hline
\end{tabular}

*p-value $<0.05$ means that there are significant differences in patients who are adherent and non-adherent

The results obtained 12 patients $(25.5 \%)$ who adhere to drug therapy, antihypertensive, and anticholesterol drugs. The finding's results were following (Hazwan and Pinatih, 2017), where the level of adherence to hypertension drugs is relatively high for about $30 \%$. Adherence to drug therapy affects the patient's blood pressure because it can be controlled. Patients who reach their target blood pressure are considered to have high levels of adherence. From Maan Withney's difference test, groups of patients who adhered and did not adhere to taking the drug toward the score obtained a value of $\mathrm{p}=$ 0.000. It is showed that there is a significant difference in scores between patients who are adherent and non-adherent in taking the drug. Uncontrolled hypertension for a long time can lead to heart attacks, enlarged hearts, and heart failure. Hypertension causes the blood vessels' muscle wall to weaken, thus developing a bulge (aneurysm), which is thought to be a blockage and rupture of the blood vessel. The high pressure in the blood vessels can leak or bleed, resulting in a stroke. Hypertension is also known to give rise to kidney failure, vision problems, and cognitive impairment (WHO, 2015).

In Table 4, some patients stated that they forgot to take drugs. No one reminds them about the time, the amount of drug that must be consumed, and because of being busy. Inadvertently forgetting to take a drug is also because the patient feels that their body condition has improved.

Table 4. Duration of taking hypertension drugs on the MARS questionnaire in hypertensive patients with dyslipidemia complications at Government Hospital in Yogyakarta in the period December 2018February 2019

\begin{tabular}{|c|c|c|c|c|c|c|}
\hline \multirow{2}{*}{ Questions } & \multicolumn{5}{|c|}{ Selection of questions } & \multirow{2}{*}{ Total } \\
\hline & Always & Often & Occasionally & Rarely & Never & \\
\hline Fail to take drug & $0(0 \%)$ & $4(8,5 \%)$ & $11(23,4 \%)$ & $16(34,0 \%)$ & $16(34,0 \%)$ & \multirow{5}{*}{$\begin{array}{c}47 \\
(100 \%)\end{array}$} \\
\hline Change the dosage & $0(0 \%)$ & $0(0 \%)$ & $3(6,4 \%)$ & $3(6,4 \%)$ & $41(87,2 \%)$ & \\
\hline Stop to take drug & $0(0 \%)$ & $1(2,1 \%)$ & $10(21,3 \%)$ & $11(23,4 \%)$ & $25(53,2 \%)$ & \\
\hline $\begin{array}{l}\text { Decided not to adhere } \\
\text { the dosage }\end{array}$ & $0(0 \%)$ & $2(4,3 \%)$ & $3(6,4 \%)$ & $4(8,5 \%)$ & $38(80,9 \%)$ & \\
\hline Take less than the rule & $0(0 \%)$ & $1(2,1 \%)$ & $4(8,5 \%)$ & $5(10,6 \%)$ & $37(78,7 \%)$ & \\
\hline
\end{tabular}




\section{Achievement of therapeutic targets}

Table 5. Achievement of therapy targets in hypertensive patients with dyslipidemia complications at the Government Hospital in Yogyakarta for the period December 2018-February 2019

\begin{tabular}{lllc}
\hline Therapy Achievement & $\begin{array}{l}\text { Numbers of } \\
\text { Respondents } \\
\text { n=47 }\end{array}$ & $\begin{array}{l}\text { Percentage } \\
(\mathbf{1 0 0 \% )}\end{array}$ & P-Value \\
\hline Achieved & 32 & 68,1 & 0,000 \\
Not Achieved & 15 & 31,9 &
\end{tabular}

* p-value $<0.05$ means that there is a significant difference between patients who have achieved and not achieved blood pressure target

The results in Table 5. showed that $68.1 \%$ of patients suffering from hypertension with dyslipidemia complications at the Government Hospital in Yogyakarta achieved the blood pressure target as the therapy, according to JNC 8. The findings showed that the blood pressure targets achievement of hypertensive patients without diabetes complications at age $<60$ years old was $<140 / 90$ $\mathrm{mmHg}$, at age $\geq 60$, years old was $<150 / 90 \mathrm{mmHg}$, and whose diabetes complications $<140 / 90 \mathrm{mmHg}$ (Dennison-himmelfarb, 2014). The blood pressure of patients with an exact lower limit of 140/90 $\mathrm{mmHg}$ or $150 / 90 \mathrm{mmHg}$ is included in the unachieved category. The factor that causes blood pressure target to be unachieved is non-adherent with the drug therapy. The Mann Withney's different test results showed the value of $p=0.000$, so this indicates a significant difference in blood pressure results between patients who achieved the target and was unachieved.

Chi-square analysis: the relationship between therapy adherent towards blood pressure target achievement

A Chi-square test was used to analyze the relationship between therapeutic adherence and the result of blood pressure target achievement. The Findings selected Fisher's trial because the $2 \times 2$ table did not meet the Chi-square requirements, in which more than $20 \%$ of cells had a smaller expected than 5 (Dahlan, 2014). The one-way hypothesis obtained a significance value of $p=0.171$, which means that the required conditions were unfulfilled, so there was no relationship between patient adherence to the blood pressure target. The Odds Ratio value (CI 95\%) was 2.955 (0.559 - 15.630). The findings showed that therapeutic adherent has a risk of 2,955 times to affect blood pressure compared with non-adherents. The patient's blood pressure probably influences it at the target limit, categorized as unachieved by the findings. Another factor that may have influenced the results could also be because the patient was classified as adhering if all five questions were met with a total score of 25 , so it is necessary to include a limit value in future findings. Chi-square test analysis of the relationship between therapy adherence with the results of blood pressure target can be seen in Table 6.

Table 6. Chi-square test analysis of the relationship between therapy adherence with the results of blood pressure target in Government Hospital in Yogyakarta for the period December 2018-February 2019

\begin{tabular}{|c|c|c|c|c|c|}
\hline \multirow{2}{*}{ Therapy Adherent } & \multicolumn{2}{|c|}{ Therapy of Target Achievement } & \multirow{2}{*}{ Total } & \multirow{2}{*}{$\begin{array}{c}p- \\
\text { value }\end{array}$} & \multirow{2}{*}{$\begin{array}{c}\text { OR } \\
(C I 95 \%) \\
\end{array}$} \\
\hline & Achieved & Unachieved & & & \\
\hline Adhere & $10(21.3 \%)$ & $2(4.2 \%)$ & 47 & 17 & 2.955 \\
\hline Not Adhere & $22(46.8 \%)$ & $13(27.7 \%)$ & $(100 \%)$ & 0.17 & $(0.559-15.630)$ \\
\hline
\end{tabular}

Note: p-value (sig> 0.05) means no relationship between therapy adherence and target achievement. 
The results showed that most of the respondents had diabetes mellitus $(74.5 \%)$ as a comorbid disease. The chi-square statistical test results on the relationship between patients' characteristics related to comorbid and therapeutic adherence obtained a p-value of $0.481(>0.05)$. The findings conclude that there is no comorbid influence on therapy adherence. The chi-square statistical test results for the relationship between patients' characteristics related to comorbid and the achievement of blood pressure targets obtained a p-value of 0.281 (>0.05). Table 1 shows that comorbid does not affect blood pressure targets achievement as presented. The findings were different from (Cahyani, 2018). It concluded a significant relationship between adherence to taking antihypertensive drugs and blood pressure $(\mathrm{p}$-value $=0.005)$, with hypertensive patients with diabetes mellitus complications considering that this patient has a high adherence level. Comorbidities may directly influence the complexity of the treatment, the amount of drug consumed, the cost, and the patient's motivation. In a study conducted, other factors, such as exercise, diet, tea consumption, coffee, and alcohol, also affect not achieving therapeutic targets. The findings lack the data collection that was carried out once when the patient had taken the drug for three months, so that the progress in achieving the target each month was not known. Also, the sample size was limited, only using hypertensive patients with dyslipidemia and other complications.

\section{CONCLUSION}

The research concluded that $25.5 \%$ of patients adhere to take antihypertensive and antidyslipidemic consumption, and $68.1 \%$ of patients achieved their blood pressure. There is no relationship between drug therapy adherence to the results of blood pressure targets achievement in hypertensive patients with dyslipidemia complications at the Government Hospital in Yogyakarta at the period December 2018-February 2019 ( $p=0.171)$.

\section{ACKNOWLEDGEMENT}

The authors thank Lembaga Penelitian dan Pengabdian kepada Masyarakat Universitas Ahmad Dahlan Yogyakarta.

\section{REFERENCES}

Anonim. (2015). Kementerian kesehatan republik indonesia.

Bakris, G., Cushman, W. C., Green, L. A., \& Izzo, J. L. (2003). The Seventh Report of the Joint National Committee on Prevention, Detection, Evaluation, and Treatment of High Blood Pressure: The JNC 7 Report, 289(May 21), 2560-2572. https://doi.org/10.1001/jama.289.19.2560

Bistara, D. ., \& Kartini, Y. (2018). Hubungan Kebiasaan Mengkonsumsi Kopi dengan Tekanan Darah pada Dewasa Muda. Jurnal Kesehatan Vokasional, 3(1), 24-27.

Bosu, W. K. (2017). systematic review, 9716(August). https://doi.org/10.3402/gha.v8.26227

Cahyani, F. M. (2018). Hubungan Kepatuhan Minum Obat Antihipertensi Terhadap Tercapainya Target Terapi Pasien Hipertensi di Puskesmas Wirobrajan Yogyakarta Melengkapi data primer yang diperoleh dari wawancara langsung dengan data pada rekam medik pasien hipertensi yang menjalani pengobatan rawat jalan di Puskesmas Wirobrajan Yogyakarta ., 1(2), 10-16.

Dahlan, M. . (2014). Statistik untuk Kedokteran dan Kesehatan Edisi 6.

Day, W. H. (2013). A global brief on Hyper - tension World Health Day 2013.

Dennison-himmelfarb, C., Handler, J., \& Lackland, D. T. (2014). 2014 Evidence-Based Guideline for the Management of High Blood Pressure in Adults Report From the Panel Members Appointed to the Eighth Joint National Committee (JNC 8), 1097(5), 507-520. https://doi.org/10.1001/jama.2013.284427

Dinkes. (2014). District Health Account.

Hardati, A. T., \& Ahmad, R. A. (2013). Aktivitas fisik dan kejadian hipertensi pada pekerja : analisis data Riskesdas 2013. 
Hazwan, A., \& Pinatih, G. N. . (2017). Gambaran karakteristik penderita hipertensi dan tingkat kepatuhan minum obat di wilayah kerja puskesmas Kintamani I, 8(2), 130-134. https://doi.org/10.1556/ism.v8i2.127

Indonesian Ministry of Health. (2015). Indonesian Health Statistics 2014. Kementerian Kesehatan Republik Indonesia (Vol. 51). https://doi.org/10.1037/0022-3514.51.6.1173

Kesehatan, K. (2013). Riset kesehatan dasar. Badan penelitian dan pengembangan kesehatan kementrian kesehatan RI.

Kishore, J., Gupta, N., Kohli, C., \& Kumar, N. (2016). Prevalence of Hypertension and Determination of Its Risk Factors in Rural Delhi, 2016.

Krousel-Wood, M., Islam, T., Webber, L. S., Re, R. N., Morisky, D. E., \& Muntner, P. (2009). New medication adherence scale versus pharmacy fill rates in seniors with hypertension. American Journal of Managed Care, 15(1), 59-66. https://doi.org/11024 [pii]

Last, A. R., College, M., Valley, F., Medicine, F., Program, R., Ference, W. J. D., ... Program, R. (2017). Risk Reduction in Adults.

Nikolov, P., Nikolova, J., Orbecova, M., Deneva T., Vladimirova, L., A. (2015). Flow Mediated Vasodilation and Some Biomarkers of Endotelial Activation in Pre-Hypertensive Object. The West Indian Medical Journal, 1-12.

Ozemek, C., Laddu, D. R., Arena, R., \& Lavie, C. J. (2018). The role of diet for prevention and management of hypertension, 1-6. https://doi.org/10.1097/HCO.0000000000000532

Ramirez, S. S. De, Enquobahrie, D. A., Nyadzi, G., Mjungu, D., \& Magombo, F. (2010). Prevalence and correlates of hypertension: a cross-sectional study among rural populations in sub-Saharan Africa, 786-795. https://doi.org/10.1038/jhh.2010.14

Weber, M. A., Schiffrin, E. L., White, W. B., Mann, S., Lindholm, L. H., Kenerson, J. G., ... Ram, C. V. S. (2014). Clinical Practice Guidelines for the Management of Hypertension in the Community A Statement by the American Society of Hypertension and the International Society of Hypertension, 16(1). https://doi.org/10.1111/jch.12237

WHO. (2015). Q \& As on hypertension, (September). 